\title{
FAKTOR KETIDAKBERHASILAN PERMA NO 1 TAHUN 2016 DI PENGADILAN AGAMA GUNUNG SUGIH
}

\author{
Zezen Zainul Ali \\ Institut Agama Islam Negeri Metro Lampung \\ Email: zezen.uje@gmail.com \\ Moelki Fahmi Ardliansyah \\ Institut Agama Islam Negeri Metro Lampung \\ Email : moelkifahmiardliansyah@metrouniv.ac.id

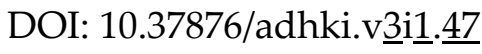

\begin{abstract}
Marriages are carried out with the aim of building a family that is sakinah mawadah and rahmah, but on the way the marriage often causes disputes that can lead to divorce, such as in the Religious Court of of Gunung Sugih which has a high divorce rate. Various attempts have been made to reduce the divorce rate, one of which is integrating mediation in the process of settling cases in court. Even so, the implementation of the mediation has not been able to meet the expected objectives because there are still many unsuccessful numbers of mediation at the Religious Court of Gunung Sugih. This research aims to determine the factors that cause the mediation process to be unsuccessful in divorce cases in particular. This research is an empirical legal research or socio-legal research. This research method used in data collection is interviews and documentation then processed and analyzed using descriptive qualitative methods. This research is expected to provide benefits and add scientific knowledge for mediators and researchers to continue working to optimize mediation as an effort to reduce the divorce rate.
\end{abstract}

Keywords: Factors, Mediation, Court, Divorce

\begin{abstract}
Abstrak
Perkawinan laksanakan dengan tujuan untuk membangun keluarga yang sakinah mawadah dan rohmah, namun pada perjalannya perkawinan seringkali menimbulkan perselisihan yang dapat menimbulkan percerian, sepertihalnya di Pengadilan Agama Gunung Sugih yang tingkat perceraian tinggi. Beragam upaya telah dilakukan untuk menekan angka perceraian, salah satunya mengintegrasikan mediasi dalam proses penyelesaian perkara di pengadilan. Meskipun demikian, pelaksanaan mediasi belum mampu memenuhi tujuan yang diharapkan karena masih banyaknya angka ketidakberhasilan mediasi di Pengadilan Agama Gunung Sugih. Penelitian ini bertujuan untuk mengetahui faktor-faktor yang menjadi penyebab proses mediasi tidak berhasil dapam perkara perceraian khususnya. Penelitian ini adalah penelitian hukum empiris atau sosio-legal research, penelitian ini metode yang digunakan dalam pengumpulan data ialah wawancara dan dokumentasi kemudian diolah dan dianalisis menggunakan metode deskriptif kualitatif. Penelitian ini diharapkan memberikan manfaat dan menambah khasanah keilmuan bagi para mediator dan para peneliti untuk terus berupaya mengoptimalkan mediasi sebagai upaya menekan angka perceraian
\end{abstract}

Kata Kunci: Faktor-faktor, Mediasi, Pengadilan, Perceraian 


\section{Pendahuluan}

Undang-undang No. 1 tahun 1974 menjelaskan tentang hakekat dari perkawinan adalah ikatan lahir dan batin antara laki-laki dan perempuan untuk membentuk suatu keluarga yang kekal dan bahagia berdasarkan Ketuhanan Yang Maha Esa. ${ }^{1}$ Karena perkawinan dianggap sebagai sesuatu yang suci maka harus dihindarkan dari permasalahan yang mengakibatkan putusnya perkawinan.

Perkawian dalam perjalanan waktu sering kali dipertemukan dengan problematika, perselisihan dan konflik sehingga dapat menimbulkan dampak pertengkaran bahkan dapat menyebabkan terjadinya perceraian. ${ }^{2}$ perceraian adalah berpisahnya antara laki-laki dan perempuan yang telah melangsungkan pernikahan sehingga mengakibatkan hilangnya hubungan suami dan istri. ${ }^{3}$

Perceraian merupakan perbuatan yang boleh dilakukan namun dibenci oleh Alloh, pada dasarnya perceraian boleh dilakukan apabila telah terjadi perselisihan dan telah adanya upaya perdamaian antara kedua belah pihak akan tetapi tidak menghasilkan kesepakan sehingga hubungan suami dan istri tidak dapat lagi dipertahankan dan apabila tetap dipertahankan tidak akan membawa kebaikan dan bahkan makan membawa kemudhorotan.

Perceraian merupakan persoalan yang sering terjadi di masyarakat, sehingganya perceraian harus dilaksakan didepan pengadilan agar adanya kepastian hukum yang didapat, apabila yang bercerai beragama muslim makan perceraian harus didepan pengadilan agama. Pengadilan agama dalam lingkungan peradilan umum merupakan pengadilan tingkat pertama yang berkedudukan di kota atau kabupaten. Fungsi dari Pengadilan agama yakni untuk memeriksa, memutus, mengadili dan menyelesaikan perkara perdata pada tingkat pertama bagi masyarakat yang beragama Islam.

Pengadilan Agama Gunung Sugih merupakan pengadilan yang emnangani perkara bagi para pencari keadilan di wilayah kabupaten Lampung Tengah. Pengadilan Agama Gunung Sugih melaksankan fungsinya untuk memeriksa, memutus, mengadili dan menyelesaikan perkara perdata agama diwilayah Kabupaten Lampung Tengah yakni salah satunya adalah perkara perceraian, Pengadilan Agama Gunung Sugih sebagai pengadilan yang berada dibawah naungan Mahkamah Agung dalam setiap perkara yang masuk dalam persidangan menyelenggarakan upaya perdamaian yakni dengan melaksanakan proses mediasi.

Mediasi adalah upaya penyelesaian perkara dipengadilan yang difasilistatori oleh pihak ketiga yang dianggap mampu untuk mempengaruhi

${ }^{1}$ Undang-undang Nomor 1 tahun 1974 jo Undang-undang nomor 6 tahun 2019

${ }^{2}$ Armansyah Matondang, "Faktor-faktor yang mengakibatkan perceraian dalanperkawinan", dalam Jurnal Ilmu Dan Sosial Politik, (Medan: Universitas Medan), Volume2/Februari 2014, h. 143.

3 Hilman Hadikusuma, Bahasa Hukum Indonesia, (Bandung: Penerbit Alumni, 1992), h.92. 
cara pandang para pihak yang berperkara sehingga anata para pihak saling memahami dan melengkapi yang pada akhirnya kedua belah pihak bersepakat untuk berdamai. ${ }^{4}$ Mediasi mengajak para pihak untuk dapat meyelesaikan permasalahan atau konflik yang dihadapi oleh para pihak dengan bantuan pihak ketiga yakni mediator yang tidak memihak, mediator berupaya mendorong para pihak untuk saling terbuka, bernegosiasai dan mencari solusi terbaik.

Peraturan Mahkamah Agung RI No. 1 Tahun 2016 menjelaskan tentang proses mediasi. Menjadi sebuah kewajiaban bagi Hakim untuk mengupayakan damai anatara kedua belah pihak, terutama dalam perkara perceraian atau alasan pertengkaran dan perselisihan. Hakim mengupayakan dengan seoptimal mungkin, kalaupun tidak berhasil dalam sidang pertama, hakim dapat meminta bantuan kepada mediator yang telah ditunjuk untuk mendamaikan perkara. Hal ini senada dengan penjelasan dalam Pasal 4 PERMA No. 1 Tahun 2008 tentang Prosedur Mediasi di Pengadilan.

Dalam perjalanan persidangan, proses mediasi menjadi salah satu kebijakan yang diambil oleh Mahkamah Agung Republik Indonesia pada praktik beracara perdata di pengadilan. Hal ini senada dengan penjelasan pasal 4 ayat (1) Peraturan Mahkamah Agung Nomor 1 Tahun 2016 Tentang Prosedur Mediasi Di Pengadilan yang berbunyi "Semua sengketa perdata yang diajukan ke Pengadilan termasuk perkara perlawanan (verzet) atas putusan verstek dan perlawanan pihak berperkara (partij verzet) maupun pihak ketiga (derden verzet) terhadap pelaksanaan putusan yang telah berkekuatanhukum tetap, wajib terlebih dahulu diupayakan penyelesaian melalui Mediasi, kecuali ditentukan lain berdasarkan Peraturan Mahkamah Agung ini." ${ }^{5}$ Dengan begitu semua yang berkaitan sengketa perdata yang diajukan ke pengadilan harus diupayakan peneyelesaian melalui proses mediasi terlebih dahulu, kecuali ditentukan lain pada PERMA tersebut.

Mediasi di pengadilan dalam pelaksanaannya sering kali mengalami kegagalan atau ketidakberhasilan antara para pihak yang berperkara. ${ }^{6}$ Dalam pelaksanaannya terkadang Peraturan Mahkamah Agung tersebut kurang begitu optimal, sehingga apabila dilihat dari tujuan mediasi belum begitu tercapai. Berdasarkan laporan Mediasi Pengadillan Agama Gunung Sugih pada tahun 2020 jumlah perkara yang masuk dalam Pengadilan Agama Gunung Gugih sebanyak 2588 perkara, tercatat sebanyak 157 perkara yang masuk untuk proses mediasi. Dari 157 perkara tersebut setelah dilaksanakan hasilnya ada 2 (dua) perkara yang berhasil dimediasi sedangkan 155 perkara tidak berhasil dimediasi dan 7 perkara gagal dimediasi. Berangkat dari data tersebut, penulis teratrik

4 Wirhanuddin, "Deskripsi Tentang Mediasi Di Pengadilan Tinggi Agama Makassar: Perspektif Hukum Islam”, AL-FIKR Volume 20 Nomor 2 Tahun 2016, h. 300.

5 Peraturan Mahkamah Agung Nomor 1 Tahun 2016 Tentang Prosedur Mediasi di Pengadilanpasal 4 ayat 1

6 Salman Ardy, dkk, “Faktor-faktor yang Mempengaruhi Gagalnya Mediasi dalam Penanganan Perkara Tanah di Pengadilan Negeri Ambon" dalam Jurnal Hukum dan Kenotariatan, h. 206 
untuk meneliti Faktor-faktor apa saja yang mengakibatkan proses mediasi tidak berhasil di Pengadilan Agama Gunung Sugih dalam Perkara Perceraian.

\section{Metode Penelitian}

Penelitian ini dilakukan di Pengadilan Agama Gunung Sugih. Banyaknya kasus perceraian dan proses mediasi yang tidak berhasil yang ditangani oleh Pengadilan Agama Gunung Sugih menjadi dasar penentuan lokasi penelitian ini. Penelitian ini merupakan penelitian sosio-legal research atau penelitian hukum empiris, yang bertujuan untuk mencari tahu faktor-faktor apa saja yang menjadi penyebab proses mediasi tidak berhasil dalam perkara perceraian. Untuk mendukung data penelitian ini maka peneliti menggunakan sumber data primer dari para hakim yang menangani perkara secara langsung dan Dokumen terkait yang dijadikan sumber sekunder. Metode pengumpulan data yang digunakan dalam penelitian ini adalah wawancara dan dokumentasi. Populasi dalam penelitian ini para hakim yang menangani proses mediasi di Pengadilan Agama Gunung Sugih. Data yang telah didapatkan kemudian dianalisis serta diolah dengan menggunakan metode deskriptif kualitatif.

\section{Pelaksanaan Mediasi di Pengadilan Agama Gunung Sugih dalam Perkara Perceraian}

Dimasukkannya mediasi dalam proses persidangan bukan berarti tanpa alasan yang kuat. Sebagai bentuk lain dari penyelesaian sengketa, mediasi mempunyai sisi keunggulan, diantaranya: "(a) mencapai kesepakatan perdamaian; (b) menempatkan kedua belah pihak di tempat yang sama; (c) prosesnya cepat, sederhana dan berbiaya rendah; bersifat informal; (e) Masingmasing pihak berupaya menyelesaikan masalah sendiri; (f) Tidak diperlukan alat bukti; (g) Hasil yang diharapkan adalah solusi yang sama-sama menguntungkan."7

Namun demikian, mediasi juga memiliki beberapa kekurangan, antara lain: 1) Mediasi hanya dapat dilakukan secara efektif apabila para pihak memiliki kemauan atau keinginan untuk menyelesaikan perselisihan melalui negosiasi; 2) Prosedur mediasi dijadikan bahan untuk penundaan penyelesaian perselisihan bagi pihak yang tidak beriktikad baik. 3) Kasus-kasus tertentu ada kemungkinan tidak dapat dimediasi, terutama berkaitan dengan ideologi dan nilai-nilai dasar, yang tidak memberikan ruang bagi para pihak untuk berkompromi; 4) Jika masalah utama dari perselisihan adalah penentuan hak, maka mediasi dianggap tidak tepat, karena perselisihan hak harus diputuskan oleh hakim, dan mediasi lebih cocok untuk menyelesaikan perselisihan yang ada kaitannya dengan kepentingan; 5) Dalam tataran normatif, mediasi tentu hanya dilakukan di bidang hukum privat, bukan di bidang hukum pidana. ${ }^{8}$

${ }^{7}$ M. Yahya Harap, Hukum Acara Perdata (Jakarta: Sinar Grafika, 2010),h. 236-238

8 Ahwan Fanani, Pengantar Mediasi (Fasilitatif), Prinsip, Metode, dan Teknik, (Semarang:

Fakultas Tarbiyah IAIN Walisongo Semarang, 2012), h. 27 
Pada lingkungan peradilan agama, mediasi cenderung dapat diproyeksikan untuk menekan angka perkara perceraian. Hal ini juga tidak terkecuali di lingkungan Pengadilan Agama Gunung Sugih. Tingkat perceraian di wilayah Kabupaten Lampung Tengah tinggi di Lampung. Berdasar Laporan hasil mediasi dalam perkara di Pengadilan Agama Gunung Sugih pada tahun 2020, jumlah perkara yang masuk dalam Pengadilan Agama Gunung Gugih sebanyak 2588 perkara, tercatat sebanyak 157 perkara yang masuk untuk proses mediasi. Dari 157 perkara tersebut setelah dilaksanakan hasilnya ada 2 (dua) perkara yang berhasil dimediasi sedangkan 155 perkara tidak berhasil dimediasi dan 7 perkara gagal dimediasi. ${ }^{9}$

Dari data tersebut menunjukkan bahwa tidak semua perkara dilakukan mediasi atau belum dilakukan mediasi. Para pihak yang tidak hadir dalam persidangan sesudah dilakukan pemanggilan sebanyak dua kali berturut-turut menjadi faktor dominan tidak terlaksananya mediasi serta dari data tersebut menenunjukan bahwa pelaksanaan mediasi di Pengadilan Agama Gunung Sugih secara langsung kurang efektif dilihar dari 157 perkara yang dimediasi hanya dua perkara yang berhasil dan sisanya tidak berhasil dimediasi.

Pelaksanaan mediasi dalam perkara perceraian di Pengadilan Agama Gunung Sugih pada tahun 2020 mengacu kepada PERMA Nomor 01 tahun 2016, semua jeis perkara yang masuk khususnya perceraian terlebih dulu harus melalui upaya mediasi, yang mana mediasi dapat dilaksakan apabila kedua belah pihak hadir dalam persidangan pertama dan saat pelaksanaan mediasi serta dihadiri oleh mediator sebagai pihak ketiga untuk mendamaikan perkara tersebut. ${ }^{10}$

Mediasi menurut Peraturan Mahkamah Agung Nomor 1 Tahun 2016 merupakan proses untuk penyelesaian sengketa melalui cara perundingan yang dibantu oleh mediator dalam memperoleh kesepakatan antara para pihak. ${ }^{11}$ Proses mediasi ini adalah upaya penyelesaian perkara melalui jalur perdamaian dengan melibatkan pihak ketiga yang berfungsi untuk penengah, tentu pihak ketiga ini harus netral tidak cenderung kepada salah satu pihak. Lebih mendalam lagi, mediasi dapat dimaknai sebagai proses bermusyawarah untuk menyelesaikan permasalahan dengan cara mencari solusi supaya dapat berdamai serta bertujuan untuk menekan angka terjadinya sebuah perceraian. ${ }^{12}$

Mediasi merupakan proses perundingan pemecahan masalah dimana pihak luar yang tidak memihak (impartial) dan netral bekerja dengan pihak yang bersengketa untuk membantu mereka memperoleh kesepakatan bersama. Mediator hanya penengah sehingga tidak memiliki wewenang dalam

${ }_{9}^{9}$ Data laporan Mediasi Pengadilan Agama Gunung Sugih, Tahun 2020

${ }^{10}$ Wawancara dengan Bapak Doni Darmawan Selaku Hakim Pengadilan Agama Gunung Sugih, Pada Tanggal 07 Maret 2021

11 Peraturan Mahkaman Agung Nomor 1 tahun 2016 tentang Proses Mediasi di Pengadilan padal 1 ayat nomor 1 .

12 Wawancara dengan Bapak Rifqi M Khaeruman, Selaku Hakim Pengadilan Agama Gunung Sugih, Pada Tanggal 10 Maret 2021. 
memutuskan sengketa diantara para pihak. Fungsi mediator hanya dapat membantu para pihak dalam menyelesaikan permasalahan-permasalahan yang sedang dipersengketakan. ${ }^{13}$

Praktik pelaksanaan mediasi itu sendiri dapat diuraikan sebagai berikut:

\section{Penetapan mediator}

Sebelum melakukan mediasi, ada hal teknis yakni proses yang harus ditempuh dalam penentuan mediator. Pertama ketika para pihak hadir dipersilahkan untuk memilih mediator di Pengadilan Agama Gunung Sugih. Ketika para pihak tidak mau memilih mediator yang ada atau tidak ada sepakat, maka hakim dapat menunjuk hakim mediator yang ada di Pengadilan secara lansung. Kemudian setelah mediator dalam perkara tersebut telah ditetapkan maka para pihak menghubungi hakim mediator terkait waktu pelaksanaan mediasi. ${ }^{14}$ Hakim Mediator menjadi penengah dari pihak yang berperkara yang telah ditetapkan dipilihkan oleh majelis hakim saat persidangan pertama.

\section{Strategi dan Teknik mediasi}

Tugas utama seorang mediator yakni memberi solusi yang dapat diterima para pihak dalam rangka perdamaian. Karakter dari proses mediasi sangatlah berbeda dengan proses persidangan yang ada kaitannya dengan hukum acara, tentu dalam proses pelaksanaan mediasi lebih lentur dan fleksibel. Apapun jenis komunikasi yang dapat menjadi jembatan bagi para pihak, dapat dilakukan untuk mencapai tujuan dari mediasi. ${ }^{15}$

Tetapi ketika para pihak tidak terlalu aktif atau bahkan cenderung tidak antusias pada saat proses mediasi, maka mediator wajib mempunyai teknik dan strategi khusus. Teknik Mediasi adalah cara atau metode yang digunakan mediator untuk mengondisikan suasana pada saat mediasi berlangsung. Dimulai dari mempertemukan para pihak yang berperkara, hingga menanyakan persoalan atau sengketa yang sedang terjadi, hingga menemukan kesepakatan yang berkenaan dengan permasalahan. Perihal semacam inilah strategi dan teknis yang harus dapat dilakukan oleh mediator yang berfungsi sebagai pihak ketiga dalam mendamaikan perkara perceraian.

Dalam hal menyampaian kata-kata yang tepat serta tidak memberi kesan bahwa berpihak kepada salah satu pihak adalah bagian kemampuan mediator terpenting dalam proses mediasi. Sebab mediator tidak boleh cenderung pada salah satu pihak yang bersengketa, melainkan harus mencari solusi dari persoalan yang sedang terjadi. ${ }^{16}$

\footnotetext{
13 Yogi Wahyudi, “ Faktor-faktor Kegagalan Mediasi di Pengadilan Agama dalam Mendamaikan Perkara Perceraian", dalam Skripsi IAIN Metro, 2020, h.22

14 Erik Sabri Rahmawari, "Implikasi Mediasi bagi Para Pihak yang Berperkara di Pengadilan Agama Malang” , dalam Jurnal De Jure: Jurnal Hukum dan Syariah, Vol. 8, No. 1, 2016, h.5

${ }_{15}$ Maksur Hidayat, Strategi dan Taktik Mediasi, ( Jakarta : Kencana, 2016), h.139

16 Wawancara dengan Bapak Rifqi M Khaeruman.
} 


\section{Proses mediasi}

Secara normatif memang di PERMA No. 01 Tahun 2016 mengatur untuk mengajukan resume, indetifikasi masalah, mengajukan kaukus dan lain sebagainya. ${ }^{17}$ Akan tetapi karena biasanya masyarakat akan lebih dibebani biaya perkara jika dilakukan secara normatif dengan proses yang panjang, maka yang dilakukan Pengadilan Agama Gunung Sugih adalah melaksanakan mediasi di hari persidangan pertama dan langsung melakukan mediasi di rung mediasi yang disediakan Pengadilan. Kaukus tersebut bersifat kasuistis, maksudnya jika mediator merasa membutuhkan kaukus maka akan diadakan, ${ }^{18}$ tapi jika mediator tidak membutuhkan maka tidak perlu kecuali perkara yang berat seperti harta bersama, karena itu dibutuhkan pendalaman perkara tentang asal usul harta tersebut. Setelah maksimal 30 hari, biasanya dalam persidangan sudah diberitahukan kapan sidang selanjutnya akan dilanjut dan tidak ada panggilan relas lagi.

Apabila mediasi dinyatakan tidak berhasil, maka mediator wajib menyatakan secara tertulis dan ditanda tangani bahwa mediasi tidak berhasil dan memberitahukan ketidak berhasilan tersebut kepada majelis hakim pemeriksa perkara lalu dilanjutkan pada pemeriksaaan dan pembuktian dalam sidang. Ketidak berhasilan mediasi tidak mengugurkan kewajiban hakim untuk terus berupaya mendamaikan sebagaimana pasal $130 \mathrm{HIR} / 154 \mathrm{Rbg}$, sehingga mengakibatkan pada setiap pemeriksaan perkara hakim pemeriksa perkara berwenang untuk mengusahakan perdamaian sampai sebelum dibacakan putusan. ${ }^{19}$

\section{Faktor-faktor yang mempengaruhi ketidakberhasilan mediasi}

Faktor yang mempengaruhi mediasi di Pengadilan Agama Gunung Sugih meliputi dari faktor eksternal dan faktor internal, yaitu sebagai berikut:

\section{Faktor Internal}

Faktor internal dalam mediasi perkara perceraian merupakan faktor yang berasal dari pihak berperkara, hakim mediator. Faktor-faktor ini meliputi:

a. Faktor perkara

Faktor perkara perceraian merupakan alasan awal mengambil langkah mengajukan gugatan atau permohonan ke Pengadilan Agama, faktor tersebut seperti:

1) Konflik yang terjadi berlarut-larut dan telah berlangsung lama, karena hal tersebut para pihak sudah tidak mau lagi mendengarkan masukanmasukan upaya damai bahkan dari mediator. ${ }^{20}$

17 Maksur Hidayat, Strategi dan Taktik..., h.99.

18 Standar Oprasional Prosedur Pelayanan Mediasi di Pengadilan Agama Gunung Sugih tahun 2020

${ }^{19}$ Muslih MZ, Pengantar Mediasi: Teori dan Praktik dalam M. Mukhsin Jamil (ed.), Mengelola Konflik Membangun Damai: Teori, Strategi, dan Implementasi Resolusi Konflik (Semarang: Walisongo Mediation Centre, 2007),h. 109

20 Wawancara dengan Bapak Doni Darmawan. 
2) Masalah yang dialami para pihak adalah masalah yang menyangkut hati maka sulit dan berat untuk didamaikan, apalagi masalahanya sudah bertumpuk-tumpuk dengan masalah yang lain. ${ }^{21}$

3) Berat dan ringan perkara yang dialami, biasanya penyebab perceraian adalah adalah masalah ekonomi yang menimbulkan ketiadak harmonisan keluarga, ada pula masalah perselingkuhan pasangan yang memang sulit untuk didamaikan.

b. Faktor para pihak

Faktor ini bisa dibilang adalah faktor yang paling dominan penyebab tidak berhasilnya mediasi diPengadilan Agama Gunung Sugih alasannya karena sebagai berikut:

1) Para pihak sebelum mengajukan perkara percerainnya ke Pengadilan Agama pasti telah mengalami pertengkaran yang hebat dan sudah didamaikan oleh pihak keluarga sehingganya dengan adanya mediasi pun tetap tidak berhasil. ${ }^{22}$

2) Salah satu pihak bersih keras atas gugatannya untuk tetap bercerai, pada umumnya alasan ketidakberhasilan mediasi adalah para pihak atau salah satu pihak memiliki keinginan yang kuat untuk bercerai meskipun perdamaian yang dilakukan secara kekeluargaan namun tidak berhasil. Tidak tercapainya perdamaian dengan cara musyawarah (kekeluargaan) maka menjadi faktor untuk sulitnya memediasi pihak- pihak perkara tersebut. ${ }^{23}$

c. Faktor Hakim mediator

Faktor ini menjadi faktoryang menjadi kendala yang ada di Pengadilan Agama Gunung Sugih, alasannya sebagai berikut:

1) Keterbatasan Mediator di Pengadilan Agama Gunungg Sugih. Pada tahun 2020 Pengadilan Agama Gunung Sugih hanya memiliki 5 hakim mediator, Keterbatasan jumlah mediator di Pengadilan Agama Gnung Sugih yang menjadi salah satu penyebab pelaksanaan mediasi tidak berjalan maksimal. ${ }^{24}$

2) Mediator dari unsur hakim cenderung kurang sabar dan telaten dengan proses mediasi, mediasi dilakukan sekali dua kali saja dengan waktu yang pendek karena hakim mediator memiliki jadwal sidang yang banyak. ${ }^{25}$

3) Hakim mediator kurang memiliki kemampuan dalam menampung aspirasi dari kedua belah pihak sehingga para pihak beranggapan

21 Ibid

22 Wawancara dengan Bapak Kusnoto Selaku Hakim Pengadilan Agama Gunung Sugih, Pada Tanggal 08 Maret 2021

${ }^{23}$ Wawancara dengan Bapak Rifqi M Khaeruman.

24 Wawancara dengan Bapak Romi Maulana Selaku Hakim Pengadilan Agama Gunung Sugih, Pada Tanggal 02 Maret 2021

25 Wawancara dengan Bapak Doni Darmawan. 
hakim mediator lebih condong ke salah satu pihak yang mengakibatkan para pihak tetap kekeh dengan pendapatnya. ${ }^{26}$

\section{Faktor Eksternal}

Faktor eksternal dalam mediasi merupakan faktor diluar dari teknis ataupun pelaksanaan mediasi yang foktor ini adalah faktor penunjang dari pelaksanaan mediasi. Faktor tersebut adalah:

a. Sarana prasarana mediasi

Sarana prasarana tidak luput dari ruangan atau tempat mediasi, hal ini sedikit banyak faktor keberhasilan dan ketidak berhasilan mediasi. Mislahnya ketika permasalahan yang menag sudah berlaurt-larut dan panas, ditmbah dengan ruang mediasi yang ikut panas serta kurang nyaman, hal ini akan menjadi salah satu faktor ketidakberhasilan mediasi. ${ }^{27}$

Tempat atau ruangan mediasi di Pengadilan Agama Gunung Sugih secara fsik sudah cukup layak, akan tetapi masih kurang kondusif dan nyaman ini dikarenakan ruangan berada dekat dengan ruang tunggu sidang sehingga suara-suara dari luar terdengar kedalam ditambah lagi ruangan tersebut merupakan akses keluar masuk pegawai bahkan terkadang pedangang keliling masuk ke ruang mediasi dan mengganggu konsentrasi jalannya mediasi. ${ }^{28}$

b. Waktu Mediasi

Waktu mediasi juga menjadi faktor yang mempengaruhi berhasil mediasi di Pengadilan Agama Gunung Sugih khsuusnya dalam perkara perceraian.

Pengadilan Agama Gunung Sugih melaksanakan mediasi terkesan buruburu, terkadang dimana hari persidangan pertama dan dihari itu juga pelaksanaan mediasi hal tersebut menjadi kurang maksimal penyelesaian perkara, jika merujuk PERMA nomor 1 tahun 2016 waktu mediasi adalah 30 hari kerja, akan tetapi ketika waktu tersebut kita berikan dampaknya peyelesaian perkara bisa lambat. ${ }^{29}$

\section{Kesimpulan}

Berdasarkan hasil analisis telah peneliti, maka disimpulkan bahwa faktorfaktor yang mempengaruhi ketidakberhasilan mediasi dalam perkara perceraian di Pengadilan Agama Gunung Sugih pada tahun 2020 meliputi dari faktor internal dan faktor eksternal. Faktor internal ketidakhasilan mediasi adalah dari para pihak itu sendiri, Faktor konflik perkara perceraian yang terjadi sudah lama dan berlarut-larut, Faktor dari pihak yang berperkara yang enggan dimediasi dan kekeh akan pendidirannya. Dan faktor dari mediator yang berasal dari kalangan hakim sebab Hakim akan kesulitan untuk memposisikan sebagai mediator sebab kecenderungan hakim adalah pemutus perkara. Dan hakim pula

\footnotetext{
${ }^{26}$ Wawancara dengan Bapak Romi Maulana.

27 Ibid.

28 Wawancara dengan Bapak Kusnoto.

${ }^{29}$ Wawancara dengan Bapak Doni Darmawan.
} 
cenderung tidak sabar dalam menangani mediasi hingga akhirnya mediasi terkesan cepat, serta hakim yang menangani perkara yang banyak sehingga mediasi tidak berjalan optimal. Faktor eksternal yang menjadi penyebab ketidakberhasilan proses mediasi di Pengadilan Agama Gunung Sugih adalah waktu pelaksanakan mediasi terkesan buru-buru yaitu di hari persidangan pertama. Tempat untuk melaksanakan mediasi di Pengadilan Agama Gunung Sugih juga masih kurang kondusif dan nyaman untuk mediasi karena tempatnya berada dekat pintu keluar masuk dan dekat dengan ruang tunggu sidang pengadilan yang bisa mengganggu konsentrasi jalannya mediasi karena ramai.

\section{Daftar Pustaka}

Ahwan Fanani, Pengantar Mediasi (Fasilitatif), Prinsip, Metode, dan Teknik, Semarang: Fakultas Tarbiyah IAIN Walisongo Semarang, 2012.

Armansyah Matondang, "Faktor-faktor yang mengakibatkan perceraian dalanperkawinan", dalam Jurnal Ilmu Dan Sosial Politik, (Medan: Universitas Medan), Volume2/Februari 2014.

Data laporan Mediasi Pengadilan Agama Gunung Sugih, Tahun 2020.

Erik Sabri Rahmawari, “ Implikasi Mediasi bagi Para Pihak yang Berperkara di Pengadilan Agama Malang" , dalam Jurnal De Jure: Jurnal Hukum dan Syariah, Vol. 8, No. 1, 2016.

Hilman Hadikusuma, Bahasa Hukum Indonesia, Bandung: Penerbit Alumni, 1992.

M. Yahya Harap, Hukum Acara Perdata ,Jakarta: Sinar Grafika, 2010.

Maksur Hidayat, Strategi dan Taktik Mediasi, Jakarta : Kencana, 2016.

Muslih MZ, Pengantar Mediasi: Teori dan Praktik dalam M. Mukhsin Jamil (ed.), Mengelola Konflik Membangun Damai: Teori, Strategi, dan Implementasi Resolusi Konflik, Semarang: Walisongo Mediation Centre, 2007.

Peraturan Mahkamah Agung Nomor 1 Tahun 2016 Tentang Prosedur Mediasi di Pengadilan.

Salman Ardy,dkk, "Faktor-faktor yang Mempengaruhi Gagalnya Mediasi dalam

Penanganan Perkara Tanah di Pengadilan Negeri Ambon" dalam Jurnal Hukum dan Kenotariatan.

Standar Oprasional Prosedur Pelayanan Mediasi di Pengadilan Agama Gunung Sugih tahun 2020

Undang-undang Nomor 1 tahun 1974 jo Undang-undang nomor 6 tahun 2019

Wawancara dengan Bapak Doni Darmawan Selaku Hakim Pengadilan Agama Gunung Sugih, Pada Tanggal 07 Maret 2021.

Wawancara dengan Bapak Kusnoto Selaku Hakim Pengadilan Agama Gunung Sugih, Pada Tanggal 08 Maret 2021

Wawancara dengan Bapak Rifqi M Khaeruman, Selaku Hakim Pengadilan Agama Gunung Sugih, Pada Tanggal 10 Maret 2021.

Wawancara dengan Bapak Romi Maulana Selaku Hakim Pengadilan Agama Gunung Sugih, Pada Tanggal 02 Maret 2021 
Wirhanuddin, “Deskripsi Tentang Mediasi Di Pengadilan Tinggi Agama Makassar :Perspektif Hukum Islam", AL-FIKR Volume 20 Nomor 2 Tahun 2016.

Yogi Wahyudi, “ Faktor-faktor Kegagalan Mediasi di Pengadilan Agama dalam Mendamaikan Perkara Perceraian”, dalam Skripsi IAIN Metro, 2020. 